\title{
Rectal ulcer due to Kayexalate deposition - an unusual case
}

\section{SUMMARY}

Sodium polystyrene sulfonate (PSP) or Kayexalate is a cation-exchange resin, widely used in the management of hyperkalaemia due to renal disease. A rare, yet potentially dangerous, adverse event related to sodium polystyrene sulfonate use is intestinal mucosal injury, especially in the colon. The injury to the gastrointestinal mucosa can range from mild and superficial to wall necrosis and bowel perforation. The mechanism that leads to mucosal damage remains unclear. However, it is believed that sorbitol, commonly given to counteract PSP's tendency to cause constipation, may play an important role in the development of gastrointestinal injury. Other potential risk factors are uraemia or end-stage renal disease, hemodynamic instability, solid organ transplantation, postoperative status and concomitant opioid administration. The authors present a case of diarrhoea and haematochezia after the administration of PSP without sorbitol, in a patient with hyperkalaemia due to acute kidney injury, in the absence of other risk factors. A colonoscopy was performed and revealed a rectal ulcer which histological findings were suggestive of mucosal injury due to Kayexalate deposition. This case supports the concept that this widely used drug can itself, without sorbitol, cause injury to the gastrointestinal wall. Even though this is a rare adverse effect, the widespread use of this medication may put a large population at risk.

KEYWORDS: Ion exchange resins. Intestinal mucosa/pathology. Cathartics/adverse effects. Colitis, ulcerative. Polystyrenes/adverse effects.

\section{INTRODUCTION}

Sodium polystyrene sulfonate (PSP) or kayexalate is an ion exchange resin, composed of an insoluble structure that acts by binding to potassium ions along the digestive tract, by exchange with sodium ions, promoting its elimination. The first studies on the use of these drugs in the treatment of hyperkalaemia date back to the 1950s and are currently widely used in the treatment of hyperkalaemia secondary to renal failure ${ }^{1-4}$. The oral route is the preferred form of administration, and rectal administra- tion is still possible when oral administration is not available. Although it is primarily used in the treatment of hyperkalaemia secondary to chronic renal disease, its relatively fast onset (2-12 hours) allows its use in acute situations, in association with other hypocalcaemia drugs ${ }^{5}$. Gastrointestinal side effects, such as nausea and constipation, are relatively frequent, and colic ulceration and/or colic necrosis is a rare but well documented complication of this therapy $^{5-7}$. Concomitant administration of PSP and sor- 
bitol to counterbalance the obstipation effect of PSP is a common practice, with the majority of reported cases of kayexalate crystal colitis occurring after the administration of this treatment combination. The mechanism by which PSP damages the intestinal mucosa is not fully understood and until recently it was thought that sorbitol was responsible for the lesion, possibly through hemodynamic phenomena of vasospasm and stimulation of prostaglandin production $^{9-11}$. Lillemeo et al. ${ }^{9}$ reported for the first time in 1987 five cases of colic necrosis following the administration of PSP and sorbitol, as an enema, in uremic patients. In the same work, the authors compared the effects of PSP alone, PSP and sorbitol, and sorbitol alone in rats, verifying that only rats exposed to sorbitol (with or without PSP) developed pathological gastrointestinal histological alterations with an impact on morbidity ${ }^{9}$. For this reason, the use of PSP with sorbitol has been discouraged ${ }^{12}$.

However, a recent systematic review of a total of 58 published cases has identified 17 cases of PSP gastrointestinal injury without sorbitol, demonstrating that intestinal necrosis may also occur when the resin is not associated with sorbitol ${ }^{6}$. Previously, Haupt and Hutchins ${ }^{13}$ had already demonstrated how inoculation of PSP into the airway of rats led to the development of inflammation after only 24 hours $^{12}$. Thus, it is currently accepted that PSP itself causes tissue damage.

\section{CLINICAL CASE}

We present the case of an 83-year-old female patient with a personal history of major depressive disorder and hypertension. The patient went to the emergency department for a clinical diagnosis, with about two weeks of evolution, of asthenia, anorexia and weight loss. According to the patient's family, she also had bizarre behaviour, urging her children to feed her, refusing to eat alone, emotional lability and isolation. She also mentioned that the onset of this condition coincided with the diagnosis of neoplasia in her husband. The objective examination performed at the emergency department revealed only signs of dehydration, without hypotension or signs of peripheral hypoperfusion. From the analytical evaluation, a new alteration of renal function was observed, with creatinine of $2.2 \mathrm{mg} / \mathrm{dL}$ and urea of 177 mg/dL (Acute Kidney Injury Network stage 2 rating) and severe hyperkalaemia $(9 \mathrm{mEq} / \mathrm{dL})$. Renal ultra- sound did not show any changes. In view of the twoweek dietary refusal, acute renal injury was considered secondary to hypovolemia due to dehydration. Serum therapy and ion-exchange resin (PSP without sorbitol) were prescribed for the treatment of severe hyperkalaemia, and the patient was admitted to the medical ward. Observation was requested by psychiatry, who considered that the patient presented a probable Histrionic Personality Disorder, proceeding to the adjustment of the psychiatric therapy. On the second day of hospitalization, there was noticeable improvement in renal function and normalization of the calemia, and resin therapy was suspended. The next day, about 48 hours after the first PSP, the patient started complaints of colicky abdominal pain and liquid diarrhoea without blood, mucus, or pus. Simultaneously, an increase in inflammatory parameters was observed, and microbiological examinations were carried out, such as uroculture, coproculture, parasitological examination, and C. difficile toxin investigation in faeces. Once the diagnosis of infectious diarrhoea was excluded, the elevation of inflammatory parameters was attributed to a urinary tract infection after isolation of Proteus mirabilis in uroculture. It was prescribed targeted antibiotic therapy and optimization of therapy and diet was performed. Due to the maintenance of diarrhoea, abdominal pain and the appearance of haematocrits, colonoscopy and abdominal and pelvic tomography (CT) were proposed, which the patient refused. Only after three weeks of hospitalization, with maintenance of the symptoms, the patient agree to these tests. A colonoscopy was performed and, despite poor intestinal preparation, which allowed only the visualization of the rectum, a depressed area in the lower rectum, partially ulcerated, without apparent necrosis was found and biopsied (Figure 1). Abdominal and pelvic CT revealed a diffuse parietal thickening of the sigmoid loops and rectal ampulla, more evident in the right anterior slope of the rectosigmoid transition, which may correspond to the inflammatory process. Finally, rectal ulcer biopsy revealed the presence of basophilic structures with mosaic pattern, similar to fish scales, surrounded by an intense active chronic inflammatory infiltrate, aspects compatible with lesion caused by ion exchange resin deposition (kayexalate crystals) (Figure 2). There was a slow and gradual symptomatic improvement, and no endoscopic or CT reassessment was performed at the option of the patient. 


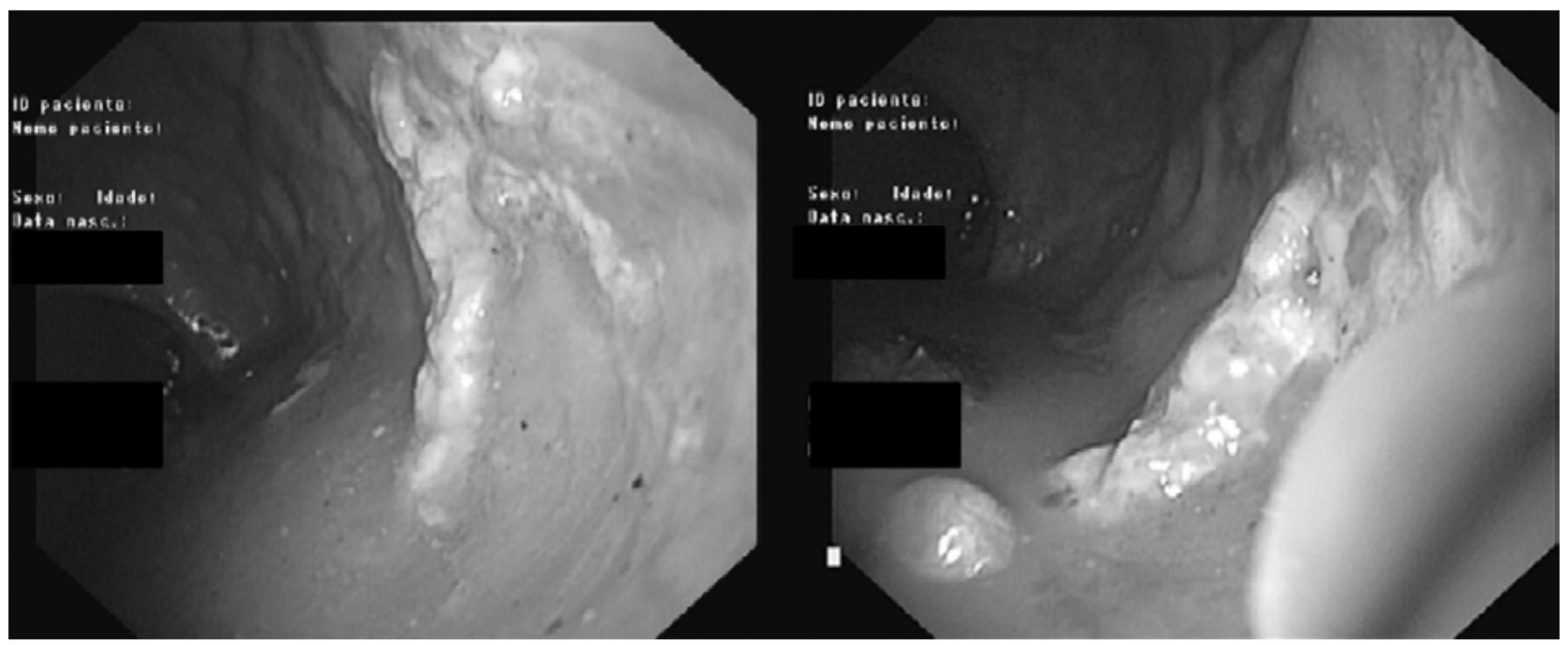

FIGURE 1

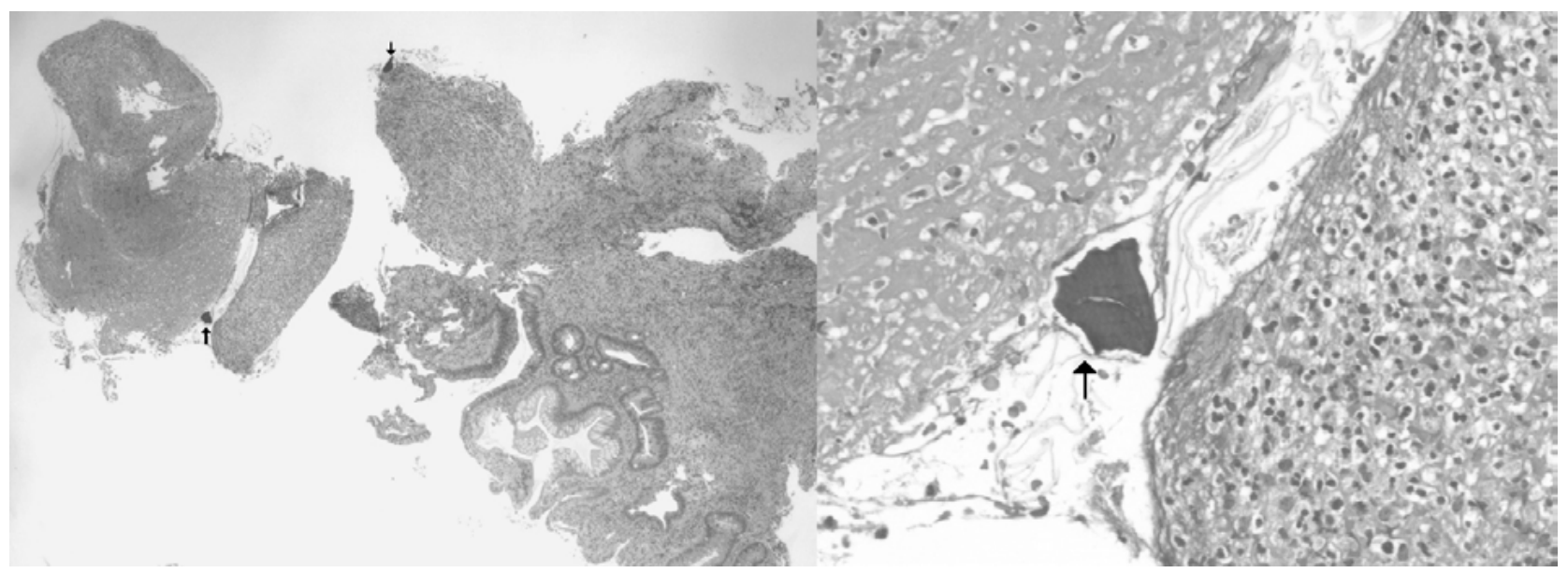

FIGURE 2

\section{DISCUSSION}

PSP crystals deposition colitis appears to occur in about $1 \%$ of patients receiving PSP and sorbitol treatment ${ }^{14,15}$. The lower number of reported cases suggests that the incidence in patients exposed to PSP alone is lower, which makes this case even more uncommon ${ }^{6}$. Several risk factors for colic injury by kayexalate crystals have been identified in the literature. In most reports, at least one of the following conditions would be present: uraemia or end-stage renal disease, hemodynamic instability, postoperative, post-renal transplantation, and concomitant administration of opioids $\mathbf{s}^{6,9,14,16-18}$. Furthermore, as already mentioned, the administration of sorbitol seems to increase the risk of development of this entity. As in the case presented, a retrospective American study identified some cases of intestinal involvement in stable patients and without chronic kidney disease, however, all had been submitted to combined sorbitol and PSP therapy ${ }^{8}$.
It can be argued that the presence of hypovolemia due to dehydration may have contributed to the development of colic injury, despite the absence of hemodynamic instability. Nonetheless, this case demonstrates that even in the absence of many known risk factors, short-term exposure (about 24 hours) to PSP without sorbitol may cause gastrointestinal damage.

Regarding the clinical presentation, the case is in agreement with the described one, since the most common symptoms are abdominal pain, low digestive haemorrhage and diarrhea ${ }^{5,6,8}$. As observed in this case, on average the symptoms appear two days after the beginning of exposure to the resin ${ }^{6}$.

It was impossible to assess the extent of the disease since the patient refused to undergo a new colonoscopy. However, although only ulcerated rectal lesion without necrosis has been documented, the presence of more extensive and severe disease is suggested by 
the results of the CT scan and the clinical presentation, which has not been proven by colonoscopy. PSP colitis presents a broad spectrum of severity ranging from superficial mucosal lesion to transmural necrosis with colic perforation ${ }^{6,8,16}$. Many less serious cases are likely to go undetected and underdiagnosed. The impossibility of performing further tests also limited the differential diagnosis to other causes of colitis. However, the temporal relationship between the onset of symptoms and exposure to PSP, clinical characteristics, biopsy result and resolution of symptoms without specific therapy allows us to affirm this diagnosis.

\section{CONCLUSION}

In this unusual case, it has been found that even a short exposure to PSP without sorbitol can cause lesion with ulceration of the intestinal mucosa. Although this type of report has proved that PSP is not an innocuous drug, presenting potentially serious adverse effects, its use is still frequent in current clinical practice. Although this is a rare adverse effect, the widespread use of PSP puts a large population at risk, so its prescription should always be weighed, especially in the presence of other therapeutic options.

\section{RESUMO}

O polistireno sulfonato de sódio (PSP) ou kayexalato é uma resina de troca iônica, amplamente usada no tratamento da hipercalemia associada à doença renal. Um efeito adverso raro, mas potencialmente grave, dessa terapêutica é a agressão à parede do trato gastrointestinal, principalmente ao nível do cólon, que pode ser ligeira e superficial ou culminar em necrose e perfuração intestinal. 0 mecanismo pelo qual o PSP lesa a mucosa intestinal não é totalmente conhecido. Contudo, pensa-se que o sorbitol, frequentemente administrado em simultâneo para contrabalançar o efeito obstipante do PSP, possa ter um papel preponderante no desenvolvimento de lesão gastrointestinal. Outros potenciais fatores de risco são a presença de uremia ou doença renal em estágio terminal, instabilidade hemodinâmica, pós-operatório, pós-transplante renal e a administração concomitante de opioides. Os autores descrevem um caso de diarreia e hematoquesias após a administração de PSP sem sorbitol, numa paciente com hipercalemia secundária a lesão renal aguda, sem outros fatores de risco para o desenvolvimento desse efeito adverso. A investigação etiológica com colonoscopia revelou a presença de uma úlcera retal, cujo estudo histológico foi compatível com lesão por deposição de cristais de kayexalato. Este relato incomum reforça o conceito de que este fármaco de uso frequente, mesmo na ausência de sorbitol, pode ser lesivo para a mucosa intestinal. Assim, e apesar de este ser um efeito adverso raro, a utilização difundida do PSP coloca uma vasta população em risco.

PALAVRAS-CHAVE: Resinas de troca iônica. Mucosa intestinal/patologia. Catárticos/efeitos adversos. Colite ulcerativa. Poliestirenos/ efeitos adversos.

\section{REFERENCES}

1. Irwin L, Berger EY, Rosenberg B, Jackenthal R. The effect of a cation exchange resin on electrolyte balance and its use in edematous states. J Clin Invest. 1949;28(6 Pt 2):1403-11.

2. Elkinton JR, Clark JK, Squires RD, Bluemle LW Jr, Crosley AP Jr. Treatment of potassium retention in anuria with cation exchange resin; a preliminary report. Am J Med Sci. 1950;220(5):547-52.

3. Evans BM, Jones NC, Milne MD, Yellowlees $H$. lon-exchange resins in the treatment of anuria. Lancet. 1953;265(6790):791-5.

4. Palmer RA, Price JD, Eden J. The treatment of hyperkalaemia by carboxylic acid resins in the upper and lower gastrointestinal tract. Can Med Assoc J. 1959;80(6):432-5.

5. Pachaly MA. Resinas trocadoras de cátions na hipercalemia aguda grave. Rev Med UFPR. 2014;1(3):103-8.

6. Harel Z, Harel S, Shah PS, Wald R, Perl I, Bell CM. Gastrointestinal adverse events with sodium polystyrene sulfonate (Kayexalate) use: a systematic review. Am J Med. 2013;126(3):264.e9-24.

7. Sterns RH, Rojas M, Bernstein P, Chennupati S. lon-exchange resins for the treatment of hyperkalemia: are they safe and effective? I Am Soc Nephrol. 2010;21(5):733-5.

8. McGowan CE, Saha S, Chu G, Resnick MB, Moss SF. Intestinal necrosis due to sodium polystyrene sulfonate (Kayexalate) in sorbitol. South Med ). 2009;102(5):493-7.

9. Lillemoe KD, Romolo JL, Hamilton SR, Pennington LR, Burdick JF, Williams GM. Intestinal necrosis due to sodium polystyrene (Kayexalate) in sorbitol enemas: clinical and experimental support for the hypothesis. Surgery. 1987;101(3):267-72.
10. Kelsey PB, Chen S, Lauwers GY. Case records of the Massachusetts General Hospital. Weekly clinicopathological exercises. Case 37-2003. A 79-year-old man with coronary artery disease, peripheral vascular disease, end-stage renal disease, and abdominal pain and distention. N Engl J Med. 2003;349(22):2147-55.

11. Zijlstra FJ. Sorbitol, prostaglandins, and ulcerative colitis enemas. Lancet. 1981;2(8250):815-6.

12. Abuelo JG. Moving away from Kayexalate, sodium polystyrene sulfate. Am J Emerg Med. 2016;34(8):1716.

13. Haupt HM, Hutchins GM. Sodium polystyrene sulfonate pneumonitis. Arch Intern Med. 1982;142(2):379-81.

14. Gerstman BB, Kirkman R, Platt R. Intestinal necrosis associated with postoperative orally administered sodium polystyrene sulfonate in sorbitol. Am J Kidney Dis. 1992;20(2):159-61.

15. Rashid A, Hamilton SR. Necrosis of the gastrointestinal tract in uremic patients as a result of sodium polystyrene sulfonate (Kayexalate) in sorbitol: an underrecognized condition. Am J Surg Pathol. 1997;21(1):60-9.

16. Joo M, Bae WK, Kim NH, Han SR. Colonic mucosal necrosis following administration of calcium polystryrene sulfonate (Kalimate) in a uremic patient. J Korean Med Sci. 2009;24(6):1207-11.

17. Albeldawi M, Gaur V, Weber L. Kayexalate-induced colonic ulcer. Gastroenterol Rep (Oxf). 2014;2(3):235-6.

18. Scott TR, Graham SM, Schweitzer EJ, Bartlett ST. Colonic necrosis following sodium polystyrene sulfonate (Kayexalate)-sorbitol enema in a renal transplant patient. Report of a case and review of the literature. Dis Colon Rectum. 1993;36(6):607-9. 